\title{
Correction to: Cold Spraying of Armstrong Process Titanium Powder for Additive Manufacturing
}

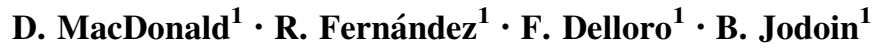

Published online: 12 June 2018

(c) ASM International 2018

\section{Correction to:}

\section{J Therm Spray Tech (2017) 26:598-609}

https://doi.org/10.1007/s11666-016-0489-2

We regret that in the original article the values in Table 2 are for copper, not for titanium.

The values of titanium are listed in the table that replaces Table 2 of the original paper.

However, it should be noted that the modeling was done with the correct data for titanium and only Table 2 in the original paper had the error.
Table 2 Material parameters used for model [taken from (Ref 51, 63)]

\begin{tabular}{lll}
\hline Symbol & \multicolumn{1}{c}{ Description } & Value \\
\hline$P$ & Density $\left(\mathrm{g} \mathrm{cm}^{-3}\right)$ & 4.51 \\
$\mu$ & Shear $(\mathrm{GPa})$ & 30 \\
$A$ & JC (MPa) & 806 \\
$B$ & JC (MPa) & 481 \\
$C$ & JC & 0.0194 \\
$n$ & JC & 0.319 \\
$m$ & JC & 0.665 \\
$\varepsilon_{0}$ & JC & 1 \\
$c_{0}$ & EOS (m s & \\
$s$ & EOS & 4950 \\
$\Gamma_{0}$ & EOS & 7 \\
$T_{\mathrm{m}}$ & Melting point $\left(\mathrm{K}^{-1}\right)$ & 1.184 \\
$c_{\mathrm{v}}$ & Heat capacity $\left(\mathrm{J} \mathrm{K}^{-1} \mathrm{Kg}^{-1}\right)$ & 1923 \\
$K$ & Thermal conductivity & 528 \\
& $\left(\mathrm{~W} \mathrm{~K}^{-1} \mathrm{~m}^{-1}\right)$ & 11.4 \\
\hline
\end{tabular}

Note: In the description, JC stands for Johnson-Cooks, EOS for Equation of State

The original article can be found online at https:// doi.org/10.1007/s11666-016-0489-2.

\footnotetext{
D. MacDonald

daniel.macdonald@uottawa.ca

1 University of Ottawa Cold Spray Laboratory, Ottawa, ON, Canada
} 